\title{
Did Hayek and Robbins Deepen the Great Depression?'
}

\author{
Lawrence H. White ${ }^{2}$ \\ Economist, George Mason University \\ Liberal Düşünce, Cilt 15, Sayı 59 - 60, Yaz-Güz 2010, s. 103 - 121
}

\begin{abstract}
Contrary to some accounts, the Hayek-Robbins ("Austrian") theory of the business cycle did not prescribe a monetary policy of "liquidationism" in the sense of passive indifference to sharp deflation during the early years of the Great Depression. There is no evidence that Hayek or Robbins influenced any "liquidationist" in the Hoover administration or the Federal Reserve System. Federal Reserve policy during the Great Depression was instead influenced by the real bills doctrine, which (despite some apparent similarities) was diametrically opposed in key respects to Hayek's norms for central bank policy.
\end{abstract}

\footnotetext{
1 Lawrence White, "Did Hayek and Robbins Deepen the Great Depression?," Journal of Money, Credit and Banking, Volume 40 Issue 4, (2008), pages 751 - 768. For the web link see http://economics.sbs.ohio-state.edu/jmcb/jmcb/07056/07056.pdf

2 The author thanks Roger Garrison, David Laidler, Masao Ogaki, George Selgin, Dick Timberlake, the (JMCB) referees, and seminar participants at the Foundation for Economic Education for comments.
} 
I think the Austrian business-cycle theory has done the world a great deal of harm. If you go back to the 1930s, which is a key point, here you had the Austrians sitting in London, Hayek and Lionel Robbins, and saying you just have to let the bottom drop out of the world. You've just got to let it cure itself. You can't do anything about it. You will only make it worse... I think by encouraging that kind of do-nothing policy both in Britain and in the United States, they did harm.

- Milton Friedman, as quoted by Gene Epstein (1999)

An increasingly common view among economic historians is that, as Ben Bernanke (2004) has put it, "the adherence of some Federal Reserve policymakers to the liquidationist thesis" during the Great Depression was among the main factors that "led policymakers astray, with disastrous consequences." Bernanke specifically cites "the infamous 'liquidationist' thesis of Treasury Secretary Andrew Mellon, who argued that weeding out 'weak' banks was a harsh but necessary prerequisite to the recovery of the banking system." Barry Eichengreen (1999, pp. 8, 12) elaborates the theme that the "dominant doctrine" of the early 1930s "was liquidationism, according to which business cycle downturns served the Darwinian function of weeding out the weak enterprises least well adapted to a dynamic economy." Eichengreen believes that liquidationism guided the Hoover administration's fiscal policy, and that the "same ideology of inaction pervaded the corridors of central banks."

Anna J. Schwartz, in an interview with Randall E. Parker (2002, pp. 111-12), identifies liquidationism with passivity in the face of deflation. She charges that the Fed of the 1930s acted in the mistaken belief that "the economy had to be submitted, subjected, to this kind of cleansing as it were, the word that has become popular nowadays, liquidationist ... you couldn't do anything to relieve the obvious deflation in the economy". In his own overview of the period, Parker (2002, p. 9) emphasizes the influence of the doctrine. The liquidationists

basically believed that economic agents should be forced to rearrange their spending proclivities and alter their alleged profligate use of resources. If it took mass bankruptcies to produce this result and wipe the slate clean so that everyone could have a fresh start, then so be it. The liquidationists viewed the events of the Depression as an economic penance for the speculative excesses of the 1920s. Thus, the Depression was the price that was being paid for the misdeeds of the previous decade.

In the paper most responsible for popularizing the term "liquidationism," $\mathrm{J}$. Bradford DeLong (1991) links the Fed's inaction to ideas propounded by Friedrich A. Hayek and Lionel Robbins: "In adopting such 'liquidationist' policies, the Federal Reserve was merely following the recommendations provided by an eco-

3 Bernanke cites two other factors as also leading policy-makers astray: the "gold standard orthodoxy" and "the incorrect view that low nominal interest rates necessarily signaled monetary ease". 
nomic theory of depressions that was in fact common before the Keynesian Revolution and was held by economists like Friedrich Hayek, Lionel Robbins, and Joseph Schumpeter." In a later paper, DeLong (1998) makes a similar argument regarding U.S. fiscal policy: Hoover and Mellon tried to keep the federal budget balanced in 1930-31 because they adhered to the Hayekian theory of the business cycle. In an online essay, DeLong (undated) puts his view of the doctrinal history the following way:

...Hoover had been one of the most enthusiastic proponents of "liquidationism" during the Great Depression himself. And the unwillingness to use policy to prop up the economy during the slide into the Depression was backed by a large chorus, and approved by the most eminent economists - most of them "Austrian" in the sense of Friedrich Hayek and Joseph Schumpeter.

DeLong goes on to characterize the Austrian chorus as holding that "in the long run the Great Depression would turn out to have been 'good medicine' for the economy, and that proponents of stimulative policies were shortsighted enemies of the public welfare."

In his own interview with Parker, Milton Friedman (Parker 2002, p. 44) characterized the Hayek-Robbins view taught at the London School of Economics as "a picture of incredible darkness." In doing so he echoed his decades-earlier description (Friedman 1974, p. 162-3) of "the London School (really Austrian) view" as a "dismal Picture." He found it dismal for teaching, among other things, "that the only sound policy was to let the depression run its course, bring down money costs, and eliminate weak and unsound firms." Though he did not use the term "liquidationism," Friedman read the Austrian view as one that counseled monetary policy-makers to do nothing to combat the sharp deflation of 1930-33. Friedman quoted extensively from Robbins' book The Great Depression to support this reading. (He also mentioned Hayek's mentor, Ludwig von Mises, but not Hayek. In the Parker interview and in the Epstein interview quoted at the outset, Friedman did name Hayek as well as Robbins.) At the University of Chicago during the 1930s, by contrast, "[f]ar from preaching the need to let deflation and bankruptcy run their course, they [Chicago economists] issued repeated pronumciamentos calling for government action to stem the deflation."

In reply to Parker's question of whether the Austrians wanted to "purge the rottenness" from the system, however, Friedman (Parker 2002, p. 43) remarked, “Well, I don't think Hayek or Lionel Robbins would have used that phrase. They would have said you simply have to use up the excessive long-lived goods and get back to an appropriate relation between capital goods and consumer goods."

DeLong's thesis that the Hoover administration and the Federal Reserve were following Austrian advice thus coincides with Milton Friedman's judgment that the Austrian advice did harm. Both suggest that "do-nothing" policy prescripti- 
ons by Hayek and Robbins contributed to deepening the Great Depression in the United States.

But is this an accurate account of Hayek's and Robbins' actual monetary and fiscal policy advice during the early years of the Great Depression? Is it an accurate account of the policies of the Hoover administration, of the Federal Reserve System, and of what influenced them? A critical examination finds DeLong's history unpersuasive on four key points.

(1) The Hayek-Robbins ("Austrian") theory of the business cycle did not in fact prescribe a monetary policy of "liquidationism" in the sense of doing nothing to prevent a sharp deflation. Hayek and Robbins did question the wisdom of re-inflating the price level after it had fallen from what they regarded as an unsustainable level (given a fixed gold parity) to a sustainable level. They did denounce, as counterproductive, attempts to bring prosperity through cheap credit. But such warnings against what they regarded as monetary over-expansion did not imply indifference to severe income contraction driven by a shrinking money stock and falling velocity. Hayek's theory viewed the recession as an unavoidable period of allocative corrections, following an unsustainable boom period driven by credit expansion and characterized by distorted relative prices. General price and income deflation driven by monetary contraction was neither necessary nor desirable for those corrections. Hayek's monetary policy norm in fact prescribed stabilization of nominal income rather than passivity in the face of its contraction. The germ of truth in Friedman's and DeLong's indictments, however, is that Hayek and Robbins themselves failed to push this prescription in the early 1930s when it mattered most.

(2) With respect to fiscal policy, the Austrian business cycle theory was silent. Hayek and Robbins did oppose make-work public programs, but they opposed them because they believed that the programs would misdirect scarce resources, not because the programs were financed by public-sector borrowing.

(3) There is no evidence that either Hoover or Mellon, or any "liquidationist" in the Federal Reserve System, drew policy inspiration from Hayek or Robbins. Given that Hayek's theory was unknown to English-language economists before he gave the lectures published as Prices and Production in 1931, it would be surprising to find that Hayek had influenced the US policy debate in 1930. ${ }^{4}$ Robbins' writings on the Depression came even later. Rather than following Hayek or Robbins, the Fed's decision-makers were following a variant of the real bills doctrine, as Richard H. Timberlake, Jr. (1993, pp. 259-83; 2007, pp. 339-43), David

\footnotetext{
${ }^{4}$ Wheelock (1992, p. 8) also links American policy to Hayek, citing Hayek (1932) and then a speech by a Federal Reserve official from 1930 as evidence that "Several key Fed officials shared Hayek's views." Like DeLong, he provides no evidence that anyone at the Fed was actually drawing from Hayek or Robbins.
} 
C. Wheelock (1991, p. 111), Allan H. Meltzer (2003, pp. 76, 138-39, 263-66, 322) and David Laidler (2003a, pp. 1259-63) have emphasized.

The Austrian and real-bills views should not be conflated. If they were, as Laidler (2003a, p. 1263 n. 11) puts it, "apparently parallel strands in the literature," then such an appearance was misleading. In key respects the two views were diametrically opposed. It may be true, as Laidler (2003b, p. 26) argues, that by offering their own non-expansionist policy advice in the early 1930s "the Austrians... lent considerable academic respectability to similar views, based on the so-called needs of trade or real bills doctrine, which at that time had wide currency in banking circles in general, and at the Federal Reserve Board in particular." Nonetheless the Austrian and real-bills views were analytically quite distinct, and the Austrians were not the source of the Fed's thinking. ${ }^{5}$

(4) Herbert Hoover explicitly rejected "liquidationist" doctrine in both word and deed. Hoover's claim that Mellon advocated liquidationism in cabinet meetings lacks corroboration from Mellon's public statements.

\section{Hayek's Theory and Its Monetary Policy Norm}

Hayek's business cycle theory led him to the conclusion that intertemporal price equilibrium is best maintained in a monetary economy by constancy of "the total money stream," or in Fisherian terms the money stock times its velocity of circulation, $M V$. Hayek was clear about his policy recommendations: the money stock $M$ should vary to offset changes in the velocity of money $V$, but should be constant in the absence of changes in $V .{ }^{6} \mathrm{He}$ accordingly lamented the shrinkage of $M$ due to the public's withdrawing reserve money from banks (as had occurred in 1929-33), referring (Hayek 1937, p. 82) to "that most pernicious feature of our present system: namely that a movement towards more liquid types of money causes an actual decrease in the total supply of money and vice versa." He declared (1937, p. 84) that the central bank's duty lay in "offsetting as far as possible the effects of changes in the demand for liquid assets on the total quantity of the circulating medium."

To stabilize the volume of nominal spending, Hayek (1935, p. 124) urged that "any change in the velocity of circulation would have to be compensated by reciprocal change in the amount of money in circulation if money is to remain neutral toward prices." Thus Hayek (1933b, pp. 164-65) held that an increased public demand to hold (i.e. to "hoard" or not spend) deposit balances would have undesirable deflationary consequences unless offset by deposit expansion:

\footnotetext{
${ }^{5}$ DeLong does not mention the real bills doctrine, instead citing only the Austrian view as an influence on the Fed. Meltzer (2003, p. 280) lumps Lionel Robbins together with real-bills advocates who held that "speculative credit and nonreal bills had to be purged."

${ }^{6}$ For secondary accounts of the evolution of Hayek's monetary policy views see Selgin (1999) and White (1999). For overviews of his cycle theory see Haberler (1986) and Garrison (1986). For an intellectual biography see Caldwell (2004).
} 
Unless the banks create additional credits for investment purposes to the same extent that the holders of deposits have ceased to use them for current expenditure, the effect of such saving is essentially the same as that of hoarding [of base money] and has all the undesirable deflationary consequences attaching to the latter. ${ }^{?}$

Hayek (1937, p. 93) was as strongly opposed to contraction in nominal income as he was to excessive expansion:

Whether we think that the ideal would be a more or less constant volume of the monetary circulation, or whether we think that this volume should gradually increase at a fairly constant rate as productivity increases, the problem of how to prevent the credit structure in any country from running away in either direction remains the same.

Hayek's ideal (ibid.) was not a do-nothing monetary policy but "an intelligently regulated international system." ${ }^{8}$

Favoring stabilization of nominal income as an ideal, Hayek and Robbins opposed efforts to stabilize the price level against real income shocks. They thought that the US price level should have been allowed to decline as real output grew with productivity improvements in the 1920s. ${ }^{9}$ Instead, in their view, the price level had been artificially propped up by the Federal Reserve's credit expansion. They regarded the downturn of 1929 as the inevitable end to an artificial boom that the credit expansion (especially in 1927-28) had fueled. ${ }^{10}$ Robbins in a 1932 letter to the Economist (quoted by Wakatabe, p. 21) wrote that "although the causes of the present depression are various and complex, there is considerable reason to believe that the main initiatory cause was the inflationary boom in America and elsewhere which preceded it."

In the "Austrian" diagnosis of the boom, credit expansion drove the interest rate artificially low, luring labor and capital into overly "roundabout" investment projects that would prove unsustainable when the interest rate returned to its natural level. Hayek (1933c, p. 178) concluded that the typical recession was an equilibrating process leading to "the re-absorption of the unemployed productive forces - men as well as equipment" into sustainable uses. The "readjustment of the economic system after a crisis" was a "process of liquidation which restores some sort of equilibrium” (Hayek 1933c, pp. 175, 174). Business bankruptcies -

\footnotetext{
7 Selgin and White (1994) point out that, absent legal restrictions, profit maximizing banks will in fact expand their deposit liabilities in response to a decrease in the public's turnover of deposits. Decreased turnover implies a reduction in a bank's optimal reserve ratio.

8 DeLong overlooks these statements of Hayek's policy norms apparently because he cannot decipher the theoretical arguments surrounding them. DeLong (1991, p. 8, n. 19) declares that "Friedrich Hayek's business cycle theory is almost impossible to grasp from his theoretical works, like Prices and Production." He assumes that Hayek's monetary policy views are adequately represented in the writings of Schumpeter and Robbins, and in Hayek's own popular political work The Road to Serfdom, so that one may neglect what DeLong (1991, p. 8., fn. 21) calls "the opaque theoretical writings of Hayek."

9 In this respect Hayek and Robbins agreed with D. H. Robertson (1926), though Robertson had a different theory of the business cycle. See Selgin (1999) and Wakatabe (2005).

${ }^{10}$ In his later Memoirs, Hoover (1952, p. 7 n. 6) quotes from Robbins' book, and endorses the view that the Fed's "easy money policies" in the 1920s fostered an unsustainable boom.
} 
liquidation in the narrow sense - might be a necessary part of the process, but these were of secondary importance to the reallocation of the factors of production (Hayek 1933c, p. 175):

The analysis of the crisis shows that, once an excessive increase of the capital structure has proved insupportable and has led to a crisis, profitability of production can be restored only by considerable changes in relative prices, reductions of certain stocks, and transfers of the means of production to other uses. In connection with these changes, liquidations of firms in a purely financial sense of the word may be inevitable, and their postponement may possibly delay the process of liquidation in the first, more general sense; but this is a separate and special phenomenon which in recent discussions has been stressed rather excessively at the expense of the more fundamental changes in prices, stocks, etc. ${ }^{11}$

Hayek (1933c, p. 176) worried that the process of readjustment after 1929 was being delayed by "the rigidity of prices and wages, which since the great war has undoubtedly become very considerable." He blamed the rigidities for the magnified unemployment and thereby for the deflation (not mentioning the US banking crisis and monetary contraction in this context), but hoped that the deflation might restore price and wage flexibility the hard way:

There can be little question that these rigidities tend to delay the process of adaptation and that this will cause a "secondary" deflation which at first will intensify the depression but ultimately will help to overcome these rigidities.

Hayek was thus ambivalent about the price deflation of 1930-33, despite the fact that its combination with falling real income clearly contravened his norm that aggregate nominal income should be stable. He considered it an open question (ibid.) whether the deflation "does not serve a necessary function in breaking these rigidities," but he also worried that "once that process of deflation has gathered momentum, it may not continue long after it has served its initial function." As we will see below, Hayek later regretted having thought that deflation could be useful.

Hayek (1933a, p. 176n.) and Robbins assumed that the gold standard remained operative. Credit expansion in the 1920s had prevented the average level of prices from falling, contrary to the gold standard's requirement that prices must fall for monetary equilibrium (the relative price of gold must rise) when produc-

\footnotetext{
11 Hayek thus associated recessionary "liquidation" with the dismantling of unprofitable firms, releasing labor and capital for other firms to use in different and more profitable activities. Using a Schumpeterian framework that focuses on the "creative destruction" of new technologies superseding old, Caballero and Hammour (1994, p. 1352) somewhat similarly view 'recessions as times of 'cleansing,' when outdated or relatively unprofitable techniques and products are pruned out of the productive system." They add that this view "was popular among pre-Keynesian 'liquidationist' theorists like Hayek or Schumpeter (see J. Bradford De Long, 1990), but need not be taken to imply, as those authors did, that recessions are 'desirable' events." It should be noted that while Schumpeter stressed technical change, Hayek attributed the clustering of unprofitable firms in a recession to the interest rate's rise back to its natural level, stranding those investments whose viability required the continuation of a low interest rate. Hayek thus did not view a recession in real activity as a "desirable" occasion to prune obsolete techniques, but rather as an unavoidable period of pruning malinvestments made during the cheap-credit boom. Caballero and Hammour (2005) find that recessions actually result in reduced (and too little) restructuring over the entire cycle, calling this a "reverse liquidationist" view.
} 
tivity improvements made the output of goods and services grow faster than the gold stock (assuming an unchanged transactions demand for gold per dollar of income). Thus the 1929 price level needed some degree of downward adjustment. (This was the "initial function" of a deflation; any further decline in the price level was "secondary" deflation. $)^{12}$ Once the adjustment of falling prices and reallocation of unemployed resources had begun, those economists who wanted to fight unemployment by using monetary expansion to re-inflate prices, Robbins wrote (quoted by Wakatabe, p. 21), "propose to cure the patient by a small dose of the same poison which has brought him to his present condition”. Robbins did not stop to consider that an equilibrating monetary expansion (to relieve a massive excess demand for money associated with a banking panic and collapse of the money multiplier) was not a "poison" in the way that a disequilibrating expansion could be (creating an excess supply of money and pushing the market interest rate below the natural rate).

DeLong (1998, p. 84) suggests that Hayekians favor living with "deep recessions" as "a necessary price for the dynamic growth efficiencies of market led economic development." But this statement better captures the view of Schumpeter, who emphasized waves of business innovation rather than credit expansions as the causes of growth spurts, than the view of Hayek (see Klausinger 1995). For Hayek, recessions were not the necessary price to be paid for dynamic growth. Investment-led growth would be sustainable - no recessionary price would be paid - if financed by voluntary savings rather than "forced savings" (credit expansion). A recession was the regrettable consequence of an unnecessary credit over-expansion, the hangover after the monetary binge.

\section{Who Were the Liquidationists?}

The most widely cited evidence that liquidationism had official influence is a passage from The Memoirs of Herbert Hoover (1952, p. 30) in which Hoover denounced Mellon for advising him not to interfere with the downturn that began in 1930 . Hoover wrote:

Two schools of thought quickly developed within our administration discussions:

First was the "leave it alone liquidationists" headed by Secretary of the Treasury Mellon, who felt that government must keep its hands off and let the slump liquidate itself. Mr. Mellon had only one formula: "Liquidate labor, liquidate stocks,

\footnotetext{
12 A back-of-the-envelope calculation of magnitude may help clarify the distinction. Since US real GDP grew a cumulative total of 29.6\% between 1921 and 1929 (Johnston and Williamson 2005), the norm of constant nominal GDP implies that the US price level should have declined by $22.8 \%$. $(1 / 1.296=.772$. Given that the US was on an international gold standard, however, world figures would be more appropriate. The US growth rate was greater than the world's, so a smaller price level decline was warranted.) The actual price level (GDP deflator) decline over that period was 3.2\%. Thus the price level was due for a downward adjustment of 19.6\% (given real GDP remaining at the 1929 level). The US price level actually dropped 25.9\% from 1929 to 1933, 6.3\% farther than would have been appropriate had real GDP remained constant, while real GDP was in fact dropping $28.7 \%$ (which warranted an increase in the price level). Given the drop in real GDP, the US experienced excess ("secondary") price-level deflation of $34.1 \%$.
} 
liquidate the farmers, liquidate real estate." He insisted that, when the people get an inflation brainstorm, the only way to get it out of their blood is to let it collapse. He held that even a panic was not altogether a bad thing. He said: "It will purge the rottenness out of the system. High costs of living and high living will come down. People will work harder, live a more moral life. Values will be adjusted, and enterprising people will pick up the wrecks from less competent people."

DeLong (1991, p. 6), Eichengreen (1999, p. 8), and many others have cited this passage as though Mellon himself actually spoke or wrote the words that Hoover puts inside quotation marks. It seems more likely, however, that the "quoted" words are merely Hoover's retrospective dramatization - perhaps caricature - of Mellon's view. The account seems intended to make Hoover look good by comparison, as Hoover (1952, p. 31) immediately followed it with a denial that he himself subscribed to the liquidationist view:

But other members of the Administration, also having economic responsibilitiesUnder Secretary of the Treasury Mills, Governor Young of the Reserve Board, Secretary of Commerce Lamont and Secretary of Agriculture Hyde-believed with me that we should use the powers of government to cushion the situation

... The record will show that we went into action within ten days and were steadily organizing each week and month thereafter to meet the changing tides-mostly for the worse. In this earlier stage we determined that the Federal government should use all of its powers...

Hoover went on to list the anti-recession initiatives his administration undertook. DeLong takes Hoover's word for it that Mellon was a liquidationist, yet inconsistently disregards Hoover's word regarding Hoover's own views and actions when asserting that Hoover too was as an "enthusiastic proponent" of liquidationism. ${ }^{13}$ Beyond his words, Hoover's anti-recession initiatives indicate that he was not guided by liquidationist doctrine.

Hoover's Memoirs do not provide a statement of liquidationist doctrine verifiably in Mellon's own words. Neither do later writers who rely solely on Hoover's say-so.

Mellon's biographers indicate that Mellon's views on anti-Depression policy were less activist than Hoover's, but were not those of the one-formula liquidationist depicted in Hoover's Memoirs. In November 1930, with the economy turning downward, Mellon (as quoted by Cannadine 2006, p. 400), saw no way to avoid “a painful process of readjustment." In a May 1931 speech (Cannadine 2006, p. 402) he warned: "Conditions today are neither so critical nor so unprecedented as to justify a lack of faith in our capacity to deal with them in our accustomed way." He concluded that the present moment was "no time to undertake drastic

\footnotetext{
13 Elsewhere DeLong (1998, pp. 74-75) does quote from Hoover's Memoirs where Hoover renounced the "liquidationists" headed by Mellon. DeLong then comments: "But Hoover's idea of how activist government should fight the Great Depression was for the government to make sure that its budget remained in surplus." DeLong does not mention Hoover's other anti-Depression initiatives.
} 
experiments which may conceivably result in breaking down the standard of living to which we have become accustomed." Mellon was not keen on Hoover's policy of summoning businessmen to the White House to urge them not to cut wages or lay workers off (Cannadine 2006, pp. 392-3). On the other hand, as an ex-officio member of the Federal Reserve Board, Mellon successfully urged the central bank to cut its discount rate after the stock market crash in October 1929, and supported subsequent rate cuts (Cannadine 2006, p. 392). In November 1929 he recommended a cut of one percentage point in personal and corporate income tax rates. He supported Hoover's proposal to increase federal construction spending as an anti-recession measure.

Mellon's speeches in the 1920s, quoted at length by Love (1929), provide no statement of liquidationism, and there is no reason to suspect that Mellon's attitude changed in the 1930s. Rather than applaud the liquidation of bankrupt firms in a recession, Mellon called the recession of 1921 a "painful period of deflation" (Love 1929, p. 212). Rather than recommend a policy of letting any financial crisis run its course, Mellon considered it the task of the Federal Reserve System to stop the crisis: the System "has already justified its existence, and it will be indispensable in any future financial crises which may arise" (Love 1929, p. 207). Furthermore, Mellon declared (Love 1929, p. 234),

The Administration has done everything possible to strengthen the Federal Reserve System, believing that its continued existence is necessary to promote stabilization not only in this country but in the world at large.

In the Annual Report of the Secretary of the Treasury on the State of the Finances for the Fiscal Year Ended June 30, 1931, Secretary Mellon (US Treasury 1931, p. 34) wrote not with cheer but with concern about the liquidation of insolvent banks:

Some of the banks affected have been unable to liquidate assets fast enough to meet the withdrawals and suspensions have occurred with the consequent shock to the community, paralysis of business, and further decline in values. Local difficulties have been accentuated and confidence shaken in other communities.

To restore confidence the Hoover Administration did not propose to let the liquidation process run its course. Rather, as Mellon noted in his report, it proposed to create a National Credit Corporation, which could lend up to $\$ 1.5$ billion to illiquid banks. The NCC would lend against bank assets that were not eligible for rediscount by the Federal Reserve. At Hoover's urging, the NCC was created by leading bankers as a private-sector organization in the fall of $1931 .{ }^{14}$ When the NCC proved ineffective and the crisis continued to deepen, Congress with Hoover's blessing in early 1932 created the $\$ 3.5$ billion Reconstruction Finance Corporation, a federal agency to bail out banks and other firms.

\footnotetext{
${ }^{14}$ According to his Memoirs (pp. 84-86), Hoover assured the participating bankers that the Federal Reserve would support the NCC by rediscounting its paper.
} 
The closest approach to "liquidationism" in 1930 was found among Federal Reserve officials who subscribed to the real bills doctrine. Eichengreen (1999, p. 12) identifies Adolph Miller of the Federal Reserve Board and the governors of the Philadelphia and Dallas Federal Reserve Banks as "outspoken advocates of letting nature run its course." Miller had been a member of the Board since its beginning in 1914, and before that an academic economist. As Laidler (2003a) notes, Miller upheld the real bills doctrine through the 1920s, though he abandoned it to advocate expansionary open market purchases in the 1930s. Evidence of the Federal Reserve Board's adherence to the real bills doctrine during Miller's tenure can be found in the Board's Tenth Annual Report of 1923, which declares: "It is the belief of the Board that there is little danger that the credit created and distributed by the Federal Reserve Banks will be in excessive volume if restricted to productive uses." ${ }^{15}$ Miller's views were formed well before Hayek or Robbins entered the debate, and there is no evidence that he was swayed by anything they wrote. Miller (1935, p. 442 n. 1) in fact explicitly rejected Robbins' (1934, p. 52) characterization of the Federal Reserve Board's policy-making in 1927-29. ${ }^{16}$

Laidler (2003a, pp. 1262-3) notes that for the real bills advocates, once it had started, the right policy was to let the Depression take its course... [I]ts exponents often saw the seeds of depression as having been sown by the discount rate cuts implemented by Benjamin Strong in 1927 to help Montague [sic] Norman maintain the newly re-established convertibility of sterling into gold at its pre-1914 parity. These cuts, it was argued, had encouraged credit creation in the United States on a scale greater than the needs of trade required, which had therefore fuelled "speculative investment" in the stock market and an unsustainable investment boom.

\section{The Real Bills Doctrine versus the Austrian Business Cycle Theory}

Laidler (2003a, p. 1263 n. 11) then comments in a footnote:

There is strong similarity between these views, and those that derived from Austrian business cycle theory as expounded by, for example, Friedrich von Hayek (1931) and Lionel Robbins (1934), which made some inroads into the American academic community in the early 1930s. See, for example Gottfried von Haberler's (1932) paper written when he was a visitor at Harvard. These two apparently parallel strands in the literature had a common ancestry in English Banking School theory, which had considerable vogue in German language academic circles from the late 19th century onwards, and the connections between them would merit further research.

Laidler is right to distinguish the real bills doctrine from the Austrian theory. He is right about the point of similarity between them, namely that the Austrians also thought that Strong's excessively expansionary policy of 1927-28 had sown the seeds for the downturn of 1929, though their criterion for excess was quite different. But Laidler is incorrect in his hypothesis that the Austrian cycle

\footnotetext{
15 As quoted by Humphrey (1982, p. 11). For more on Miller's views see Timberlake (2007, pp. 239-43).

${ }^{16}$ In the same article, Miller (1935, p. 456) also indicated that Secretary Mellon was in the minority opposing the Miller-led Board's real-bills-inspired policy of "direct pressure" in 1929.
} 
theory, like the real bills doctrine, had its ancestry in Banking School theory. The Banking School of the 1840s had held the Bank of England blameless for any business cycles, on the grounds that gold convertibility, and the operation of the "law of the reflux," made it impossible for the Bank to over-expand. Hayek built directly on the cycle theory of Ludwig von Mises, and Mises built on the cycle theory developed by the Banking School's opponents, the Currency School, who charged the Bank of England with over-expanding and then being forced by gold losses to contract. ${ }^{17}$

The Austrian theory (Hayek 1933a, 1935; Robbins 1934) combined the Currency School's monetary theory of the trade cycle with Böhm-Bawerk's and Wicksell's capital and interest theories. ${ }^{18}$ A credit expansion that reduced the market interest rate (or prevented it from rising with credit demand), to a value below the intertemporal equilibrium rate (the "natural rate"), would foster unsustainable investments. The real bills doctrine, as Laidler (2003a, p. 1260) elsewhere points out, had nothing directly to say about interest rate policy: "In particular, though it advised that banks should discount only (but all) good quality bills offered to them, it was silent on how to choose the interest rate at which such credit was to be granted." But the real-bills norm of an elastic supply of credit implied that the interest rate should be kept from rising when credit demand rose. Laidler notes that central banks became freer to pursue this elastic-credit-supply norm after policy changes to enable inflationary financing for the First World War considerably weakened the constraint the international gold standard had previously placed on their policies.

The central bank policy of raising or lowering interest rates in response to gold outflows or inflows - classic Bank of England rate policy - was not derived from the real bills doctrine, but instead overrode it and thereby neutralized the real bills doctrine's influence. Once the classic gold-flow policy was abandoned during and after the First World War, the real bills doctrine came into its own as a guide for central bank credit creation. Lacking the Austro-Wicksellian notion of the natural rate of interest as a benchmark for neutral policy, the real bills doctrine judged excess credit creation by an asset-quality test: any bank lending on real bills of exchange (commercial paper issued to finance goods-in-process) was not excessive, but any lending on other assets was.

\footnotetext{
${ }_{17}$ Mises' theory has even more in common with the views of a third school of thought in the English debates, the Free Banking School (see White 1995, p. 108). The Currency School held that the English country banks had sometimes overissued in unison. The Free Banking School insisted, as did Mises, that only a central bank like the Bank of England could significantly over-issue, so that decentralized note-issue ("free banking") was the best arrangement for avoiding over-expansions and the crashes that followed. Hayek, however, accepted the Currency School view that competing commercial banks could also over-expand, and was therefore more ambivalent toward free banking (see also White 1999). Both Mises and Hayek explicitly criticized Banking School doctrines. For a brief summary of the debate among the Currency, Banking, and Free Banking Schools, see Schwartz (1987).

${ }^{18}$ For an overview of Böhm-Bawerk's and Wicksell's theories see Lutz (1968, chs. 1-2).
} 
A key contrast between the real bills doctrine and Hayekian monetary policy norms arises, as Roger Garrison (2006, pp. 12-13) notes, when business firms want to invest more, perhaps to exploit new inventions. To finance additional investment, firms seek additional loans. The demand curve for loanable funds shifts out. Hayek's neutral-money norm calls for letting the market interest rate rise with the increase in the demand for loanable funds, so that the rising market rate accurately signals the increased relative scarcity of present goods and thereby accurately guides intertemporal allocation. ${ }^{19}$ What Hayek called the "interest brake" curbs potential over-investment. The real bills doctrine, by contrast, calls (in Garrison's words) for "accommodating the needs of trade" by "increasing the supply of credit to match each new increase in the demand for credit," in effect producing an artificially flat supply curve for loanable funds that prevents the interest rate from rising in the short run. Hayek (1933a, p. 179-80) sharply criticized such an elastic credit supply in his first book on the business cycle ${ }^{20}$ :

The immediate consequence of an adjustment of the volume of money to the "requirements" of industry is the failure of the "interest brake" to operate as promptly as it would in an economy operating without credit. This means, however, that new adjustments are undertaken on a larger scale than can be completed; a boom in thus made possible, with the inevitably recurring "crisis." The determining cause of the cyclical fluctuation is, therefore, the fact that on account of the elasticity of the volume of currency media the rate of interest demanded by the banks is not necessarily always equal to the equilibrium rate, but is, in the short run, determined by considerations of banking liquidity. ${ }^{21}$

Policy based on the real bills doctrine - expanding the banking system's liabilities to accommodate an increase in the quantity of business credit demanded at the prevailing interest rate, and conversely letting the system's liabilities contract when credit demand was slack - was, for Hayek, not just a minor error. It was a principal source of the boom-bust cycle the world was experiencing.

Strict adherence to the classical real bills doctrine would have denied the central bank the power to purchase government securities in the open market, so the real bills doctrine needed modification to serve as a guide to the proper volume of open market purchases. ${ }^{22}$ Economists at the Fed developed a modification that Allan H. Meltzer calls the "Riefler-Burgess doctrine”. Meltzer (2003, p. 398) summarizes its importance for Fed policy in the 1930s as follows:

\footnotetext{
19 In Hayek's (1933a, p. 168) words: "Assuming, as is preferable, that this increased demand was not caused by a lowering of [the banks'] own interest rates, this additional demand is always a sign that the natural rate of interest has risen."

20 Hayek's book was first published in German in 1929. Garrison (2006, p. 13) quotes the first part of this passage.

${ }^{21}$ Emphasis in the original. Hayek here (1933a, p. 180 n.) footnoted an even earlier (1926) work in which he "already dealt with the elasticity of bank credit as the cause of cyclical fluctuations." He cited Frank A. Fetter's critique of the procyclical impact of the real bills doctrine.

22 Humphrey (2001) discusses the modifications by which Fed economists after the First World War turned the real bills doctrine into a quantitative guide for open market operations.
} 
Federal Reserve records suggest that the real bills or Riefler-Burgess doctrine is the main reason for the Federal Reserve's response, or lack of response, to the depression. With few exceptions, the Federal Reserve governors accepted this framework as a guide to decisions. They believed that a low level of member bank borrowing and low nominal interest rates suggested there was no reason to make additional purchases.

The details of the Riefler-Burgess doctrine need not concern us here, except the fact that its development owed nothing to the Austrian theory of the business cycle. If the Fed had taken Hayek's theory seriously, they would have tried to make the supply of credit less elastic in response to shifts in credit demand. If they had taken his policy norm seriously, they would have been trying to stabilize nominal income, which in the face of a declining broad money stock and declining velocity (as in 1929-32) would have meant substantial expansion of the monetary base.

\section{Why didn't Hayek and Robbins Call for Counter-Deflationary Measures?}

Hayek and Robbins can be seriously faulted for failing to take their own policy norm seriously: they failed to call for central banks to do what they could to counter the sharp monetary contraction and crushing deflation during 1930-33. Each later faulted himself. In a 1975 talk Hayek noted that "the inherent instability of credit" could turn a recession with extensive unemployment into a self-feeding deflationary contraction. He then commented (Hayek 1975, p. 5):

I am the last to deny - or rather, I am today the last to deny - that, in these circumstances, monetary counteractions, deliberate attempts to maintain the money stream, are appropriate.

I probably ought to add a word of explanation: I have to admit that I took a different attitude forty years ago, at the beginning of the Great Depression. At that time I believed that a process of deflation of some short duration might break the rigidity of wages which I thought was incompatible with a functioning economy. Perhaps I should have even then understood that this possibility no longer existed. ... I would no longer maintain, as I did in the early '30s, that for this reason, and for this reason only, a short period of deflation might be desirable. Today I believe that deflation has no recognizable function whatever, and that there is no justification for supporting or permitting a process of deflation.

Hayek went on (pp. 12, 13) - in response to questions from Gottfried Haberler about whether more could have been done to prevent deflation in the 1930s - to reiterate his support for the norm of stabilizing nominal income, and to point out that this had always been his theoretical policy norm:

The moment there is any sign that the total income stream may actually shrink, I should certainly not only try everything in my power to prevent it from dwindling, but I should announce beforehand that I would do so in the event the problem arose... You ask whether I have changed my opinion about combating secondary deflation. I do not have to change my theoretical views. As I explained before, I have 
always thought that deflation had no economic function; but I did once believe, and no longer do, that it was desirable because it could break the growing rigidity of wage rates. Even at that time I regarded this view as a political consideration; I did not think that deflation improved the adjustment mechanism of the market. ${ }^{23}$

Later in his career, Lionel Robbins also regretted his advice against using monetary expansion to arrest the deflation. In a 1966 speech in the House of Lords he confessed: "I was on the wrong side: I opposed measures of reflation which I now think might have eased the situation; and although I do not flatter myself that my attitude influenced action in any respect, I shall always most seriously regret having done so." ${ }^{4}$ In his Autobiography (Robbins 1971, p. 154) he explained his perspective: even supposing that "the assumption that the original diagnosis of excessive financial ease and mistaken real investment was correct - which is certainly not a settled matter," he now recognized that the banking crisis had changed the situation into one of ongoing contraction of the broad money stock and shrinking velocity. The shrinkage of nominal expenditure not only forced the price level down but also depressed real activity. At that point, a policy of refusing to expand the monetary base "was as unsuitable as denying blankets and stimulants to a drunk who has fallen into an icy pond, on the grounds that his original problem was overheating." Whatever the extent of "inappropriate investments" being corrected, the processes of equilibration "were completely swamped by vast deflationary forces." Robbins thus belatedly recognized something that he and Hayek could have recognized in the early 1930s, namely that combating the contraction of nominal income - as called for by Hayek's theoretical monetary policy norm - was not inconsistent with the Austrian account of why the expansionary monetary policy of the late 1920s had been unsustainable. ${ }^{25}$

\section{Conclusion}

In allowing the contraction of nominal income (MV) to proceed without offsetting monetary countermeasures in the $1930-33$ period, American policymakers were not acting on the advice of F. A. Hayek and Lionel Robbins, but on the advice of Federal Reserve officials who subscribed to versions of the real bills doctrine. There is no evidence that Hoover administration or Federal Reserve officials were reading Hayek or Robbins in the early 1930s. Hayek's monetary policy norm in fact called for the stabilization of nominal income (MV), and thus for central bank action to prevent its contraction. Hayek and Robbins themselves, however, did not call for

\footnotetext{
${ }^{23}$ Hayek recognized an equilibrating function to a mild deflation of consumer prices driven by increasing productivity. To be consistent, his statements above must all refer to a deflation in excess of that rate, driven by monetary contraction, what (following Haberler) Hayek called a "secondary deflation".

${ }^{24} \mathrm{I}$ am indebted to an anonymous referee for this reference.

25 This was the position taken contemporaneously by Gottfried Haberler (1932, pp. 52), who after sketching Hayek's theory of why the boom was bound to collapse, added: "If some banks - those nerve centers where innumerable strands of credit relations come together - are involved and become bankrupt, a wave of pessimism is bound to come: as a secondary phenomenon a credit deflation is likely to be the consequence of the general distrust and nervousness... I do not deny that we can and must combat the secondary phenomenon-an exaggerated pessimism and an unjustified deflation."
} 
policy to stabilize nominal income at the time. Hayek thought, based on ad hoc ("political") reasoning and contrary to his own theoretical norm, that a brief deflation might have a salutary effect on recovery by restoring flexibility to wages. Robbins spurned anti-deflationary monetary expansion on the grounds that excessive financial ease had led to false prosperity and its collapse in the first place. Both later regretted their mistake in not promptly recognizing the need to prevent the damage done by the contraction of money and nominal income.

\section{References}

Bernanke, Ben S. (2004). “Money, Gold, and the Great Depression.” H. Parker Willis Lecture in Economic Policy, Washington and Lee University, Lexington, Virginia (March 2). http://132.200.33.130/boarddocs/Speeches/2004/200403022/default.htm

Caballero, Ricardo J., and Mohamad L. Hammour. (1994). “The Cleansing Effect of Recessions." American Economic Review 84, 1350-1368.

Caballero, Ricardo J., and Mohamad L. Hammour. (2005). "The Cost of Recessions Revisited: A Reverse-Liquidationist View." Review of Economic Studies 72, 313-341.

Caldwell, Bruce. (2004). Hayek's Challenge: An Intellectual Biography of F.A. Hayek. Chicago: University of Chicago Press.

DeLong, J. Bradford. (1991). “Liquidation Cycles and the Great Depression.” Working paper, Harvard University and NBER, 1991. http://econ161.berkeley.edu/pdf_files/Liquidation_Cycles.pdf

DeLong, J. Bradford. (1998). “Fiscal Policy in the Shadow of the Great Depression." In The Defining Moment: The Great Depression and American Economy in the Twentieth Century, edited by Michael D. Bordo, Claudia Goldin, and Eugene N. White, pp. 67-85. Chicago: University of Chicago Press.

DeLong, J. Bradford. (undated). “Friedrich A. von Hayek.” http://www.j-bradford- delong. net/Economists/hayek.html

Eichengreen, Barry. (1999). “The Keynesian Revolution and the Nominal Revolution: Was There a Paradigm Shift in Economic Policy in the 1930s?” UC Berkeley working paper (March). http://www.econ.berkeley.edu/ eichengr/research/castronov.pdf

Epstein, Gene. (1999). “Mr. Market [Interview with Milton Friedman].” Hoover Digest, no. 1. http://www.hooverdigest.org/991/epstein.html

Garrison, Roger W. (1986). “Hayekian Trade Cycle Theory: A Reappraisal.” Cato Journal 6, 437-53. 
Garrison, Roger W. (2006). "From Keynes to Hayek: The Marvel of Thriving Macroeconomies." Review of Austrian Economics 19, 5-15.

Haberler, Gottfried. (1932). "Money and the Business Cycle." Reprinted in Ludwig von Mises et al., The Austrian Theory of the Trade Cycle and Other Essays, compiled by Richard Ebeling. Auburn: Mises Institute, 1996.

Haberler, Gottfried. (1986). "Reflections on Hayek's Business Cycle Theory." Cato Journal 6, 421-35.

Hayek, Friedrich A. (1932). “The Fate of the Gold Standard.” In Money, Capital, and Fluctuations, ed. Roy McCloughry (Chicago, IL: University of Chicago Press, 1984), 118-135.

Hayek, Friedrich A. (1933a). Monetary Theory and the Trade Cycle, translated by N. Kaldor and H. M. Croome. London: Cape.

Hayek, Friedrich A. “Saving” (1933b). Reprinted in Hayek, Profits, Interest and Investment. London: Routledge, 1939.

Hayek, Friedrich A. (1933c). "The Present State and Immediate Prospects of the Study of Industrial Fluctuations". Reprinted in Hayek, Profits, Interest and Investment. London: Routledge, 1939.

Hayek, Friedrich A. Prices and Production, $2^{\text {nd }}$ ed. (1935). London: Routledge.

Hayek, Friedrich A. Monetary Nationalism and International Stability. (1937). London: Longmans, Green.

Hayek, Friedrich A. A Discussion with Friedrich A. von Hayek. (1975). Washington, DC: American Enterprise Institute.

Hoover, Herbert. (1952). The Memoirs of Herbert Hoover, Vol. Three: The Great Depression 1929-1941. New York: Macmillan.

Humphrey, Thomas M. (1982). “The Real Bills Doctrine.” Federal Reserve Bank of Richmond Economic Review 68, 3-13.

Humphrey, Thomas M. (2001). “The Choice of a Monetary Policy Framework: Lessons from the 1920s." Cato Journal 21, 285-313.

Johnston, Louis D., and Samuel H. Williamson. "The Annual Real and Nominal GDP for the United States, 1790 - Present.” Economic History Services, April 1, 2006. http:// eh.net/hmit/gdp/

Klausinger, Hansjorg. (1995). “Schumpeter and Hayek: Two Views of the Great Depression Re-examined.” History of Economic Ideas 3, 93-127. 
Laidler, David. "Meltzer's History of the Federal Reserve." (2003a). Journal of Economic Literature $41,1256-71$.

Laidler, David. "The Price Level, Relative Prices, and Economic Stability: Aspects of the Inter-war Debate." (2003b). University of Western Ontario working paper. http://economics.uwo.ca/econref/WorkingPapers/researchreports/wp2003/wp2003_10.pdf

Love, Philip H. (1929). Andrew Mellon: The Man and His Work. Baltimore: F. Heath Coggins $\&$ Co.

Lutz, Friedrich A. (1968). The Theory of Interest. Chicago: Aldine.

Meltzer, Allan H. (2003). A History of the Federal Reserve, Vol. 1: 1913-1951. Chicago: University of Chicago Press.

Mises, Ludwig von. (1980). The Theory of Money and Credit. Indianapolis: Liberty Press.

Parker, Randall, ed. (2002). Reflections on the Great Depression. Northampton, MA: Edward Elgar.

Robbins, Lionel. (1934). The Great Depression. London: Macmillan.

Robbins, Lionel. (1971). Autobiography of an Economist. London: Macmillan.

Robbins, Lionel. (1979). Against Inflation: Speeches in the Second Chamber, 1965-1977. London: Macmillan.

Robertson, D. H. (1926). Banking Policy and the Price Level: An Essay in the Theory of the Trade Cycle. London: P. S. King and Son.

Schwartz, Anna J. (1987). “Banking School, Currency School, Free Banking School.” In J. Eatwell,. M. Milgate, and P. Newman, eds., The New Palgrave: Dictionary of Economics (London: Macmillan).

Selgin, George. (1999). "Hayek versus Keynes on How the Price Level Ought to Behave." History of Political Economy 31, 699-722.

Selgin, George, and Lawrence H. White. (1994). "How Would the Invisible Hand Handle Money?” Journal of Economic Literature 32, 1718-49.

Timberlake, Richard H., Jr. (1993). Monetary Policy in the United States: An Intellectual and Institutional History. Chicago: University of Chicago Press.

Timberlake, Richard H., Jr. (2007). “Gold Standards and the Real Bills Doctrine in U. S. Monetary Policy.” Independent Review 11, 325-54.

United States Treasury. (1931). Annual Report of the Secretary of the Treasury on the State of the Finances for the Fiscal Year Ended June 30, 1931. Washington, DC: U.S. Government Printing Office. 
Wakatabe, Masazumi. (2005). "Was the Great Depression the Watershed of Macroeconomics?: The Impact of the Great Depression on Economic Thought Reconsidered." Working paper. http://www.ires.ucl.ac.be/CONFERENCE/21_01_2005/Wakatabe.pdf

Wheelock, David C. (1991). The Strategy and Consistency of Federal Reserve Monetary Policy, 1924-1933. Cambridge: Cambridge University Press.

Wheelock, David C. (1992). "Monetary Policy in the Great Depression: What the Fed Did, And Why." Federal Reserve Bank of St. Louis Review 74 (March), 3-28.

White, Lawrence H. (1995). Free Banking in Britain, $2^{\text {nd }}$ ed. London: Institute of Economic Affairs.

White, Lawrence H. (1999). "Hayek's Monetary Theory and Policy: A Critical Reconstruction." Journal of Money, Credit and Banking 31, 109-20. 